\title{
Microclimate of the nest and egg water loss of the Eider Somateria mollissima and other waterfowl in Spitsbergen
}

\author{
HERMANN RAHN, JOHN KROG AND FRIDTJOF MEHLUM
}

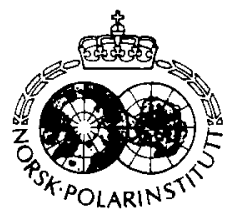

\begin{abstract}
Rahn, H., Krog, J. \& Mehlum, F. 1983: Microclimate of the nest and egg water loss of the Eider Somateria mollissima and other waterfowl in Spitsbergen. Polar Research I n.s. 171-183.

Temperature gradients in the nest and within the egg. nest humidity as well as eggshell conductance and rate of egg water loss of the Eider Somateria mollissima and other waterfowl were studied at Ny-Álesund. Spitsbergen $\left(78^{\circ} 55^{\prime} \mathrm{N}\right.$ latitude). These studies suggest a specific interrelationship between eggshell conductance and maintenance of an appropriate temperature and humidity environment of the nest, resulting in an egg water loss rate which is optimal for hatching success. In spite of low ambient temperatures of less than $3^{\circ} \mathrm{C}$ and very low absolute humidities of less than 4 torr (similar to those found in hot deserts). the nest's microclimate and rate of water loss were similar to those reported for nests and eggs in temperate climates.
\end{abstract}

Hermann Rahn, Department of Physiology. State University of New York, Buffalo, N.Y. 14214. U.S.A.; John Krog. Department of Zoophysiology, University of Oslo. Blindern. Oslo 3. Norway; Fridijof Mehlum. Norwegian Polar Research Institute. Rolfstangveien 12, 1330 Oslo Lufthavn, Norway; November 1982 (accepred May 1983)

\section{Introduction}

While much has been written about the distribution and nesting behavior of birds in the Arctic, little if anything is known about the microclimate of nests of birds that colonize particularly the farthest reaches of the polar region. What are the egg temperatures and nest humidities that such birds can maintain during incubation under severe climatic conditions encountered in the high arctic area $\left(79^{\circ} \mathrm{North}\right)$, and how do these compare with nesting conditions in more southern latitudes.

Irving \& Krog (1956) examined nest air temperatures of arctic birds in Alaska ( $68^{\circ}$ North) to see whether the eggs were exposed to lower or more variable temperatures than in temperate regions. Using thermocouples affixed to the nest they determined the nest air temperature in seven incubating species and found that the median incubation temperature of 49 records was between $33^{\circ} \mathrm{C}$ and $35^{\circ} \mathrm{C}$, and in $74 \%$ of the records, between $33^{\circ} \mathrm{C}$ and $37^{\circ} \mathrm{C}$. These values were similar to those obtained by Huggins (1941) in the Cleveland, Ohio, area ( $41^{\circ}$ latitude); Huggins found a mean temperature among eggs of 37 species to be $34^{\circ} \mathrm{C}$, S.D. 2.4. Irving \& Krog concluded that 'during the periods of incubation and brooding the growth of birds proceeds at wellregulated temperatures in the changeable weather of temperate and arctic climates. The regulation of temperature during incubation and brooding is accomplished by the behavior of the parent birds'.

In this study we examined the microclimate of the nest in three species of waterfowl nesting in Kongsfjord on Spitsbergen ( $79^{\circ}$ latitude), during the latter half of June (see map. Fig. 1). The daily mean air temperatures were considerably lower than those in the Alsaka study and did not exceed $4^{\circ} \mathrm{C}$, while the mean ambient absolute humidity was below 4 torr $(\mathrm{mm} \mathrm{Hg})$, equivalent to an air moisture content of $4 \mathrm{mg}^{-1}$. Not only did we examine the temperature gradients within the eggs as well as the nest and the absolute humidity of the nest's microclimate, but also the egg water loss and eggshell conductance. Most of the information was obtained for the eggs and nests of the Eider (Somateria mollissima), with additional data from the nests of the Barnacle Goose (Branta leucopsis) and the Long-tailed Duck (Clangula hyemalis) and the eggs of the Pink-footed Goose (Anser brachyrhynchus). 

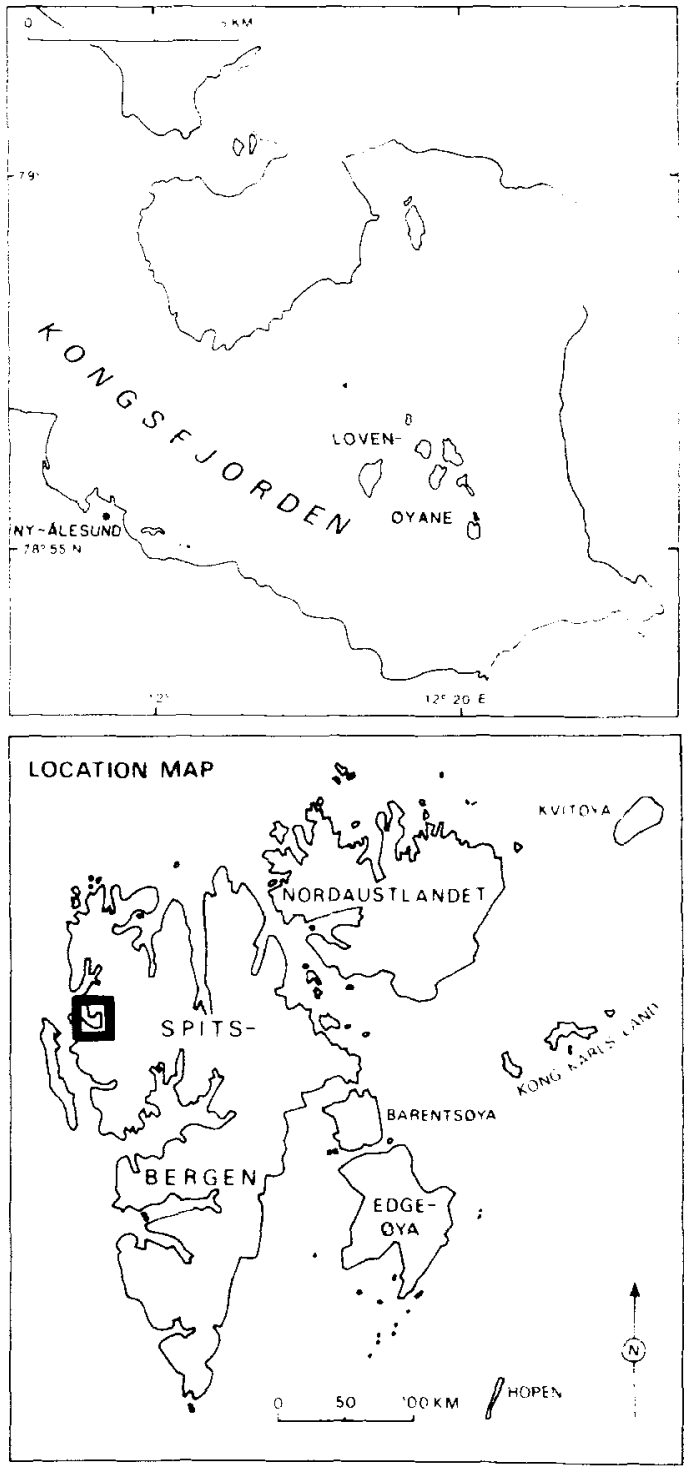

Fig. I. Location map.

\section{Methods}

\section{Temperature measurements}

Egg temperature. - Copper-constantan thermocouples were secured at various levels in either tresh Eider or chicken eggs. To prevent such eggs from turning in the nest, they were secured on a small board with epoxy resin as shown in Fig. 2. The thermocouple leads exiting beneath the board were buried and extended $10-15 \mathrm{~m}$ beyond the nest. This was of sufficient length so that the incubating parent would not leave the nest when readings were made at various times of the day. Temperatures were read from a Kane-May Temperature Recorder. As each nest was visited, the various leads were individually plugged into this hand-held digital read-out device. On one occasion egg temperatures of Eider eggs were measured by direct insertion of a thermistor into the egg at various levels. Readings at the top, center, and bottom of the egg were made in succession within 30 seconds of the fernale leaving the nest.

Brood patch temperature. - A small piece of styrofoam plastic was mounted on top of the egg to serve as insulation from the remainder of the egg. A small thermocouple was then mounted on top of the insulation to come in contact with the skin of the brood patch. The leads from this thermocouple were affixed with wax to the outside of the shell as shown in Fig. 2.

Nest air temperature. - These were recorded continuously in the nest of the Long-tailed Duck using a thermistor which was mounted as shown in Fig. 2.

Body temperature. - Female Eiders were captured using a $4 \mathrm{~m}$-long handle net on the nest. While one person held the body, the other opened the bill and inserted a wooden bit to lodge across the angle of the bill so that it stayed open. A small

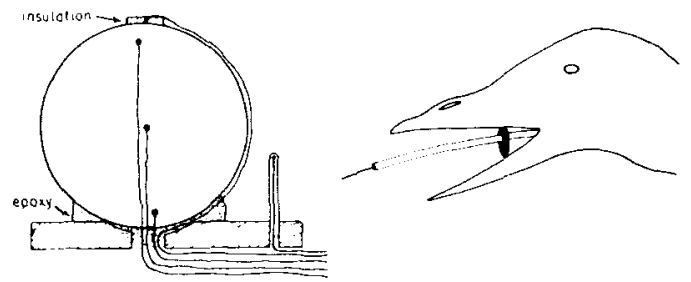

Fig. 2. Schematic section through Eider egg showing locations of thermocouples and their leads brought out through a hole in the wooden platform which serves to keep the egg in the upright position once placed in the nest. Thermocouple mounted on a styrofoam insulation was used to measure the brood patch temperature. Its leads were attached with wax to the outside of the egg. Next to the egg is mounted a thermistor for air temperature recordings. On the right is shown the wooden bit in the angle of the Eider's bill. A polyethylene tube (outside diameter $3 \mathrm{~mm}$ ) is advanced through a hole in the bit down the esophagus a distance of $36 \mathrm{~cm}$ to the proventriculus. The thermocouple initially retracted is then advanced $3 \mathrm{~mm}$ beyond the end of the tube for the temperature reading. 
hole in this bit allowed a third person to advance a $(3 \mathrm{~mm}$ o.d.) polyethylene tube into the proventriculus (see Fig. 2). After placement a $0.9 \mathrm{~mm}$ thermocouple junction inside the tube was advanced $3 \mathrm{~mm}$ beyond the terminal end of the tube and the temperature read on the Kane-May Temperature Recorder. The whole operation from the time of capture to the temperature read-out was accomplished in less than one minute.

Nest and ground,temperatures. - Temperatures at the bottom of the down layer and a few $\mathrm{cm}$ below the down layer were measured with thermocouple junctions in Eider nests from which the female had been flushed. The depth of the compressed down layer and the ground beneath the nests were also measured.

Ambient air temperatures. - These were daily averages taken from the official log of the local weather station located with $0.5 \mathrm{~km}$ radius of the Eider nests.

\section{Humidity measurements}

Nest humidity. - Egg diffusion hygrometers were prepared as previously described (Rahn et al. 1977). Briefly, chicken eggs were emptied, cleaned, dried, and filled with a desiccant, silica gel. They were then calibrated by exposure to a constant water vapor pressure in a sealed container. The daily gain in water vapor was measured and provided the necessary calibration of the diffusive eggshell conductance expressed in mg $\mathrm{H}_{2} \mathrm{O}$ day $^{-1}$ torr $^{-1}$ (1 torr $=1 \mathrm{~mm} \mathrm{Hg}$ vapor pressure). Once calibrated, the eggs were weighed just prior to insertion into the nest and again 2-4 days after removal from the nest. From the average daily weight gain in the nest and the eggshell conductance, the mean water vapor pressure can then be calculated, since $\mathrm{P}_{N}=$ $\dot{\mathrm{M}}_{\mathrm{H}_{2} \mathrm{O}} / \mathrm{G}_{\mathrm{H}_{2} \mathrm{O}}$, where $\mathrm{P}_{\mathrm{N}}=$ the mean water vapor pressure in the nest, torr; $\dot{\mathrm{M}}_{\mathrm{H}_{2} \mathrm{O}}=$ the mean daily weight gain of water, $\mathrm{mg}$ day $^{-1} ; \mathrm{G}=$ the shell conductance, $\mathrm{mg} \mathrm{day}^{-1}$ torr $^{-1}$. The chicken egg hygrometers were readily accepted in all the nests.

Ambient humidity. - The absolute ambient humidity was calculated from the mean air temperature and the relative humidity values of the weather station records, and is also expressed in terms of the water vapor tension, torr.
Egg humidity. - The water vapor pressure in the eggs provides the pressure head for the flux of water vapor which leaves the egg during incubation. This vapor pressure is essentially saturated and thus can be estimated from the egg temperature using standard water vapor pressure-temperature tables.

\section{Weight changes of eggs during incubation}

These were determined at various intervals using Pesola scales.

\section{Egg and shell dimensions}

Initial egg mass. - Since eggs lose appreciable amounts of water during incubation, the air cells were displaced by water in order to establish the initial egg mass; this technique was recently validated (Grant et al. 1982). Weight measurements were made on a torsion balance to within $\pm 3 \mathrm{mg}$.

Initial egg density. - This value was calculated from the egg dimensions provided by Schönwetter (1960), as recently reported by Rahn et al. (1982).

Surface area. - This value was derived from the allometric relationship between surface area and egg mass (Paganelli et al. 1974).

Length and width. - These were measured using calipers as previously described (Rahn et al. 1976).

Shell weight. - After eggs were emptied the shell was dried, first in air and then for at least one day in a desiccator before weighing on a torsion balance within $\pm 3 \mathrm{mg}$ accuracy.

Shell thickness. - This was measured to three significant figures with a ball point micrometer. Twenty-one measurements from representative areas were taken and averaged for each egg.

\section{Pore counts of shell}

Shell fragments were boiled in a $2.5 \mathrm{KOH}$ solution to remove all proteinaceous material. They were then etched in concentrated nitric acid for several seconds, the time depending upon the thickness of the shell. The etching process enlarges the pores so that painting the inside of the shell with a water soluble dye will draw the solution to the 
outside rim of the pores. The pores in each of twenty $1 / 4 \mathrm{~cm}^{2}$ areas were counted and averaged. and the total number per egg calculated on the basis of its surface area. The average coefficient of variation of the 20 pore counts for each egg is about $20 \%$.

\section{Egg shell conductance}

This was measured according to the method of Ar et al. (1974). Eggs were placed at constant room temperature in desiccators with silica gel. The daily weight loss was established and divided by the saturation water vapor pressure at that temperature to yield the eggshell conductance to water vapor expressed in $\mathrm{mg} \mathrm{H}_{2} \mathrm{O}$ day $^{-1}$ torr $^{-1}$.

\section{Results}

\section{Temperatures}

Body temperature of ten female incubating Eiders was determined at about 2400 on 2 July. The values ranged from 38.2 to $39.5^{\circ} \mathrm{C}$. with a mean value of $39.1^{\circ} \mathrm{C}$. S.D. 0.4 . The brood patch temperatures had a mean value of $38.5^{\circ} \mathrm{C}$ in Eiders and $37.7^{\circ} \mathrm{C}$ in the Barnacle Goose (Table 1). The width of an Eider egg is $5 \mathrm{~cm}$ (Table 5) and the implanted thermocouples were situated $0.5 \mathrm{~cm}$ from the top, in the center, and $0.5 \mathrm{~cm}$ above the
Table 2. Local temperatures in 12 Eider nests. S.D. in parentheses.

\begin{tabular}{lrr}
\hline & $\begin{array}{l}\text { Bottom of } \\
\text { down layer }\end{array}$ & $\begin{array}{r}\text { Gravel-sand } \\
\text { below down }\end{array}$ \\
\hline $\begin{array}{l}\text { Distance below egg } \\
\text { or below down. cm. }\end{array}$ & $3.3(0.8)$ & $4.4(1.8)$ \\
Mean temperature. ${ }^{\circ} \mathrm{C}$ & $20.4(3.8)$ & $10.3(3.3)$ \\
\hline
\end{tabular}

bottom of the shell. From Table 1 it can be seen that a $7.6^{\circ} \mathrm{C}$ temperature difference was observed over a distance of about $4 \mathrm{~cm}$. The thermocouple in the center of the egg registered a mean value of $33.6^{\circ} \mathrm{C}$ about halfway between the top and the bottom thermocouples, and indicates a linear temperature gradient over the extreme distance. It is of interest to note that by direct insertion of a thermistor into six Eider eggs the mean top to bottom temperature difference was only $4.1^{\circ} \mathrm{C}$. The implanted thermocouples in the Barnacle Goose egg showed a mean difference of $5.3^{\circ} \mathrm{C}$.

At the bottom of the down layer, $3.3 \mathrm{~cm}$ below the bottom of the egg, the temperature had fallen to $20.4^{\circ} \mathrm{C}$. In the gravel-sand substrate $4.4 \mathrm{~cm}$ below the down, the temperature averaged $10.3^{\circ} \mathrm{C}$ (Table 2). The ambient mean daily air temperatures during the period average about $4^{\circ} \mathrm{C}$.

\section{Humidities}

The absolute humidities of the nest's microclimate

Table I. Measurement of brood patch and egg temperatures by implanted thermocouples in the eggs of Eider (between 25 June and + July and the Barnacle Goose (between 30 Junc and 3 July). Egg tcmperatures were also obtained in Eider eggs by direct insertion of a thermistot into top. center. and bottom of egg (28 June)

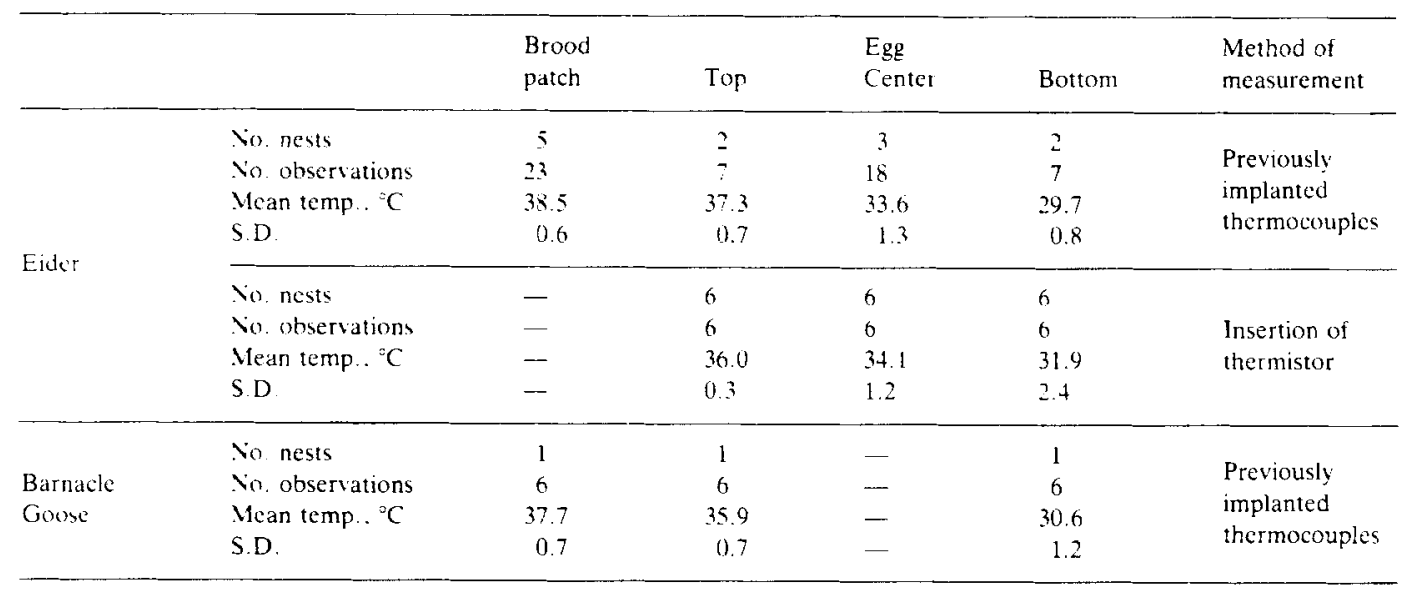


Table 3. Absolute humidity values in nest of Eider, Barnacle Goose, and Long-tailed Duck as well as ambient absolute humidity and temperature values.

\begin{tabular}{|c|c|c|c|c|c|}
\hline & \multirow[b]{2}{*}{ Date } & \multirow[b]{2}{*}{ Hyg. No. } & \multicolumn{2}{|c|}{ Absolute humidity } & \multirow[b]{2}{*}{$\begin{array}{c}\text { Ambient temp. } \\
\left({ }^{\circ} \mathrm{C}\right)\end{array}$} \\
\hline & & & $\begin{array}{l}\text { Nest } \\
\text { (torr) }\end{array}$ & $\begin{array}{l}\text { Ambient } \\
\text { (torr) }\end{array}$ & \\
\hline \multirow{3}{*}{$\begin{array}{l}\text { Eider } \\
\text { (2 nests) }\end{array}$} & 27-30 June & 7 & 18.0 & 4.2 & 3.6 \\
\hline & 30 June-3 July & 6 & 20.3 & 4.3 & 4.3 \\
\hline & & Mcán & 19.2 & 4.3 & 4.0 \\
\hline \multirow{8}{*}{$\begin{array}{l}\text { Barnacle } \\
\text { Goose } \\
\text { (1 nest) }\end{array}$} & 14-17 June & 3 & 18.7 & 4.0 & 1.4 \\
\hline & 17-20 June & 6 & 20.6 & 3.7 & 1.9 \\
\hline & $20-23$ June & 1 & 14.1 & 4.2 & 1.7 \\
\hline & 23-27 June & 5 & 16.0 & 4.0 & 2.1 \\
\hline & 27-30 June & 9 & 16.9 & 4.2 & 3.6 \\
\hline & 30 June-2 July & 2 & 17.6 & 4.3 & 4.3 \\
\hline & & Mean & 17.3 & 4.1 & 2.5 \\
\hline & & S.D. & 2.2 & 0.2 & 1.2 \\
\hline \multirow{4}{*}{$\begin{array}{l}\text { Long-tailed } \\
\text { Duck } \\
\text { (1 nest) }\end{array}$} & $8-13^{*}$ June & 1 & $10.9^{*}$ & $3.1^{*}$ & $1.8^{*}$ \\
\hline & 13-16 June & 2 & 15.7 & 3.8 & 2.0 \\
\hline & $16-20$ June & 5 & 14.0 & 3.8 & 1.7 \\
\hline & & Mean & 14.9 & 3.8 & 1.9 \\
\hline
\end{tabular}

* Incubation had not started during this period. Values omitted from mean.

for the three species are shown in Table 3, giving the date during which a particular egg hygrometer was in the nest. In the Barnacle Goose nest we have a continuous record of nest humidity over an 18-day period, with remarkably little change and maintaining an average value 13 torr higher than the absolute ambient humidity. During six days of integrated records of the Eider nest the nest humidity was maintained 15 torr above the ambient humidity. The nest humidity of the Long-tailed Duck during seven days of recording was somewhat lower than for the first two species, maintaining an 11 torr difference above the ambient humidity.

\section{Weight loss of eggs}

The mean weight loss for Eider eggs was 0.59 $\mathrm{g} /$ day. Assuming this to be an average throughout incubation, this would result in 25 days in a net loss of $14.8 \mathrm{~g}$ or $14 \%$ of the initial egg mass of $103 \mathrm{~g}$ (Table 5). For the Barnacle Goose the daily weight loss of $0.57 \mathrm{~g}$ for 24.5 days of incubation would result in a net loss of $14 \mathrm{~g}$, or $13 \%$ of the initial mass of $109 \mathrm{~g}$. In the Long-tailed Duck the average value after the initiation of incubation was $151 \mathrm{mg} \mathrm{day}^{-1}$. However, this mean rate during the first 15 days does not reflect the progressive increase in the daily rate from 100 to $180 \mathrm{mg}$ day $^{-1}$ during four successive weighings during this

Table 4. Average weight losses of eggs during incubation.

\begin{tabular}{lccccc}
\hline & No. nests & No. eggs & $\begin{array}{c}\text { Interval } \\
\text { (days) }\end{array}$ & $\begin{array}{c}\text { Weight loss } \\
\left(\mathrm{mg}^{-1} \text { day }\right.\end{array}$ & 590 \\
\hline Eider & 8 & 27 & 4 & 572 & 32 \\
Barnacle Goose & 1 & 4 & 19 & 15 & 69 \\
Long-tailed Duck & 1 & 6 & 15 & 3 \\
\hline
\end{tabular}




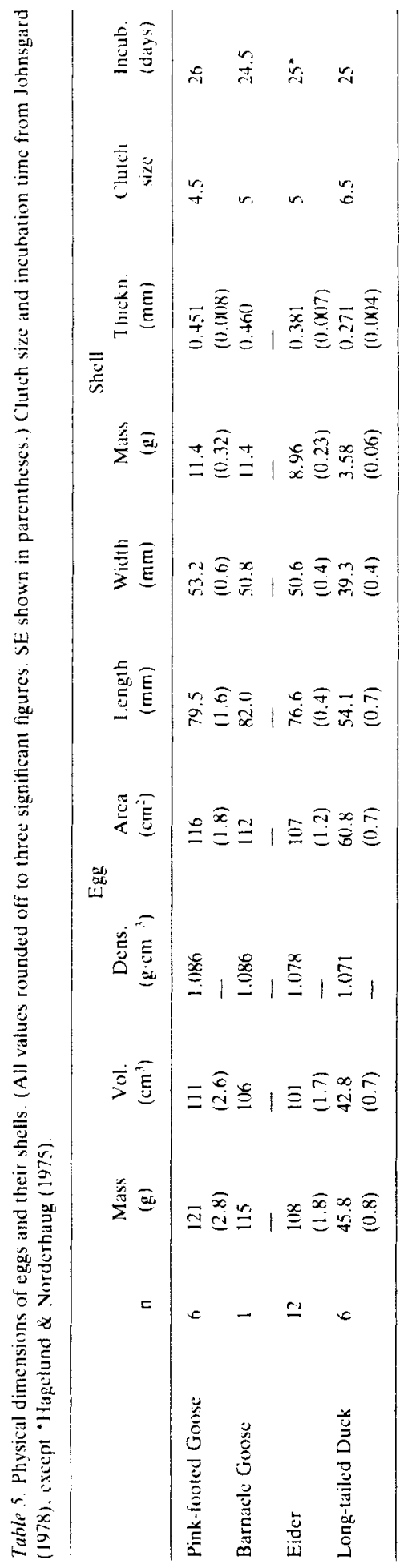

period, and thus does not provide a good basis for an overall estimate of incubation water loss.

\section{Egg dimensions}

These are shown in Table 5 and agree within 3\% or less with the values for egg mass, length, width, shell mass, and shell thickness provided by Schönwetter (1960). The indicated typical clutch size and incubation times are taken from Johnsgard (1978).

\section{Shell conductance and pore dimensions}

The mean values for water vapor conductance of the shell, $G$, the pore length or shell thickness, $\mathrm{L}$, and the number of pores in each egg are shown in Table 6. Since water vapor transport across the shell obeys Fick's first law of diffusion, the shell conductance is proportional to the total pore area, $A_{p}$, and inversely proportional to the length of the pore, L. (Paganelli 1980). Substituting the measured values for $G$ and $L$ allows one to calculate $A_{p}=0.447 \mathrm{G} \cdot \mathrm{L}$ (Rahn et al. 1976; Paganelli 1980) as shown in Table 6. Compared with the surface area of the egg (Table 5), $A_{p}$ is very small; for example, in the Eider it is equal to $(3.7 / 10,700)$ or $0.03 \%$ of the egg's surface area. All gas exchange during incubation is limited to this small fraction of the shell's surface.

When the total pore area, $A_{p}$, is divided by the total number of pores, $N$, one obtains the average cross sectional area of the individual pores as well as the pore radius, assuming that all pores have uniform diameter throughout their length. The actual shapes of the pores for the Eider, Pinkfooted Goose, and Barnacle Goose are drawn to scale in Fig. 3. They were copied from the pore casts made by Tyler (1964). According to Tyler (1964) and Board et al. (1977), examination by light and electron microscopy reveals that these pores are partially obstructed by the remains of the cuticle and organic spherules which fill the upper cup of the pores. This is shown diagramatically in the center of the lower row in Fig. 3. To the left are three pore casts of the Eider and to the right are the calculated dimensions. Since this calculation is based on a functional performance, namely, the conductance, the derived dimensions are smaller than the actual pores because of the obstruction and therefore one must speak of an effective pore area and an 

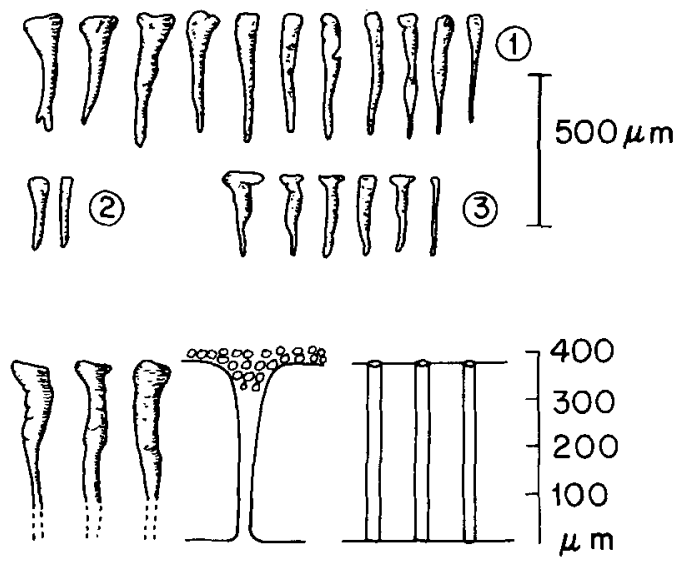

Fig. 3. Pore casts reproduced from Tyler (1964). 1. Pink-footed Goose, 2. Barnacle Goose, and 3. Eider. In the lower row are shown from left to right three pore casts of Eider, a diagrammatic cross-section through pore showing the organic spherules which obstruct the pore cup according to Tyler (1964) and Board et al. (1977). On the right are the calculated effective pore dimensions for Eider eggs. See text.

effective pore radius (Paganelli 1980; Board 1982).

Our shell conductance measurements of Eider eggs were done on freshly laid eggs before incubation had started. To our surprise these values were very much lower than one would have expected (Ar \& Rahn 1978) and lower than those that H.R. had previously obtained in incubated Eider eggs in Alaska and Canada. We believe that these low conductance values were due to the presence of cuticular covering plugging the pores which had not yet been removed by pro- longed contact with the brood patch. Similar differences in conductance value were observed between unincubated and incubated eggs of the Long-tailed Duck. For this reason the shell conductance values for the Eider listed in Table 6 are based on the average value of nine eggs previously measured. As far as we know this is the first observation in non-passeriform eggs that the water vapor conductance will change after incubation is initiated. That such changes occur in the small eggs of passeriform birds has been previously reported by Carey (1979), Hanka et al. (1979), and Sotherland et al. (1980).

\section{Discussion}

\section{Body temperatures}

Our mean value of $39.1^{\circ} \mathrm{C}$ for the incubating Eider is similar to the "abdominal temperature of the sitting Eider' of $39.6^{\circ} \mathrm{C}$ reported by Rol'nik (1970). Kossack (1947) reported a 'cloacal temperature for incubating Canada Geese' of $40.9^{\circ} \mathrm{C}$ $(\mathrm{n}=2)$ and Caldwell \& Cornwell (1975) mentioned a 'deep body temperature' of $41^{\circ} \mathrm{C}$ for the Mallard.

\section{Egg temperatures}

Outer surface measurements. - By attaching temperature recording devices to the outer surface of natural eggs during natural incubation large temperature differences have been recorded

Table 6. Shell conductance, pore length (= shell thickness), pore number per egg, and calculated total pore area and individual pore dimensions. Standard error in parentheses.

\begin{tabular}{|c|c|c|c|c|c|c|}
\hline & $\begin{array}{l}\text { Conductance } \\
\text { (G) } \\
\mathrm{mg} \cdot \mathrm{day}^{-1} \cdot \text { torr }^{-1}\end{array}$ & $\begin{array}{l}\text { Measured } \\
\text { Pore length } \\
\text { (L) } \\
\text { mm }\end{array}$ & $\begin{array}{l}\text { Number of pores } \\
(\mathrm{N})\end{array}$ & $\begin{array}{l}\text { Total pore area } \\
\qquad \begin{array}{c}\left(A_{p}\right) \\
\mathrm{mm}^{2}\end{array}\end{array}$ & $\begin{array}{l}\text { Calculated } \\
\text { Individual pores } \\
\text { Area } \\
\mathrm{m} \mu^{2}\end{array}$ & $\begin{array}{c}\text { Radius } \\
\mathrm{m} \mu\end{array}$ \\
\hline Eider & $\begin{array}{l}21.6^{*} \\
(0.8)\end{array}$ & $\begin{array}{c}0.381 \\
(0.007)\end{array}$ & $\begin{array}{c}14,266 \\
(544)\end{array}$ & 3.7 & 260 & 9.1 \\
\hline Pink-footed Goose & $\begin{array}{l}29.5 \\
(1.8)\end{array}$ & $\begin{array}{c}0.451 \\
(0.008)\end{array}$ & $\begin{array}{c}16,277 \\
(939)\end{array}$ & 6.0 & 368 & 10.8 \\
\hline Barnacle Goose & 22.7 & $\begin{array}{c}0.460 \\
-\end{array}$ & $\begin{array}{c}11,927 \\
-\end{array}$ & 4.7 & 394 & 11.2 \\
\hline Long-tailed Duck & $\begin{array}{l}11.6 \\
(0.4)\end{array}$ & $\begin{array}{c}0.271 \\
(0.004)\end{array}$ & $\begin{array}{l}9,373 \\
(684)\end{array}$ & 1.4 & 149 & 6.9 \\
\hline
\end{tabular}

* See text 
between the top and bottom surfaces. Both Rol'nik (1970) and Drent (1970) have reviewed the literature. For example, Burke (1925) measured these differences daily in five nests of the chicken throughout the whole incubation period, while Drent (1970) made similar observations in the Herring Gull (Larus argentatus). In both species the top of the egg under the brood patch maintained remarkably stable temperatures between 39.2 and $39.5^{\circ} \mathrm{C}$, while the bottom surface of the eggshell gradually increased in temperature during the incubation period from about 30 to $34^{\circ} \mathrm{C}$ in the chicken and from about 27 to $35^{\circ} \mathrm{C}$ in the Herring Gull. In the Kittiwake (Rissa tridactyla), the top of the egg maintains a fairly constant temperature of $38^{\circ} \mathrm{C}$ throughout most of the incubation period, while the nest's surface below the egg (not the bottom surface of the egg) was approximately $11^{\circ} \mathrm{C}$ lower (Barrett 1980).

Temperature differences within the egg. - A few of these have been reported in natural eggs during natural incubation and are given in Table 7 including our own observations. The egg width of each species is also given. allowing one to caiculate the approximate temperature gradient within the egg. $\Delta{ }^{\circ} \mathrm{C} / \mathrm{cm}$. As may be noted, these vary greatly and are not necessarily related to egg size but more likely reflect the particular stage of embryonic development. In our study the thermocouples were implanted in freshly laid eggs with no appreciable heat production of the embryo nor chorioallantoic circulation. Such eggs might be expected to have the largest gradients of $1^{\circ} \mathrm{C} / \mathrm{cm}$ or more as shown in Table 7. In the other reported studies the age of the embryo, the degree of chorioallantoic development. and the possible disturbance of the normal metabolism and circulation by implantation of the thermocouple are unknown quantities. Such factors would influence not only the absolute temperature but also the temperature gradient within the egg.

Central and air cell egg temperatures. - Egg temperatures frequently reported are assumed to be central egg temperatures. The average value reported by Drent (1975) for 16 non-passeriform species is $35.8^{\circ} \mathrm{C}$, S.D. 1.1 . One approach is to record the air cell temperature, which does not interfere with the normal development of the embryo. Caldwell \& Cornwell (1975) measured air cell temperatures in Mallard eggs (Anas platyrhynchos) during natural incubation. During the early stages these temperatures were about 33 to $34^{\circ} \mathrm{C}$ and during the last week of incubation averaged $38^{\circ} \mathrm{C}$, S.D. 1.2 , with an overall average of $36.3^{\circ} \mathrm{C}$. S.D. 2.5 , for the whole incubation period. Similar studies in the Canada Goose (Branta canadensis) gave values of $38.5^{\circ} \mathrm{C}$, S.D. 0.7 (Kossack 1947) and $37.9^{\circ} \mathrm{C}$, S.D. 1.1 (Cooper 1978). The latter study also showed a gradual increase in air cell temperature as incubation proceeded as well as a marked circadian rhythm, with lowest temperature occurring between 0400 and 0500 and the highest value between 1400 and 1600 hours, with a mean difference of $3.0^{\circ} \mathrm{C}$.

Table 7. Temperature differences within natural eggs during natural incubation, their egg width and calculated temperature gradients, $\Delta^{\circ} \mathrm{C} / \mathrm{cm}$.

\begin{tabular}{|c|c|c|c|c|c|c|}
\hline & Ref. & Top & $\begin{array}{c}\text { nperatur } \\
\text { Center }\end{array}$ & Bottom & $\begin{array}{l}\text { Egg width } \\
\mathrm{cm}\end{array}$ & $\begin{array}{c}\text { Temp. grad } \\
\Delta^{\circ} \mathrm{C} / \mathrm{cm}\end{array}$ \\
\hline $\begin{array}{l}\text { Eider } \\
\text { (Somateria mollissima) }\end{array}$ & - & 37.3 & 33.6 & 29.7 & 5.1 & 1.5 \\
\hline $\begin{array}{l}\text { Barnacle Goose } \\
\text { (Branta leucopsis) }\end{array}$ & - & 35.9 & - & 30.6 & 5.1 & 1.0 \\
\hline $\begin{array}{l}\text { Laysan Albatross } \\
\text { (Diomedea immutabilis) }\end{array}$ & 1 & 36.8 & - & 34.6 & 6.9 & 0.3 \\
\hline $\begin{array}{l}\text { Royal Tern } \\
\text { (Sterna maxima) }\end{array}$ & 2 & 39.2 & 37.8 & - & 4.4 & 0.6 \\
\hline $\begin{array}{l}\text { Kittiwake } \\
\text { (Rissa tridactyla) }\end{array}$ & 3 & 38.0 & 36.4 & -- & 4.2 & 0.8 \\
\hline $\begin{array}{l}\text { Great Egret } \\
\text { (Casmerodius albus) }\end{array}$ & 2 & 36.9 & 34.3 & - & 4.1 & 1.3 \\
\hline $\begin{array}{l}\text { Cattle Egret } \\
\text { (Bubulcus ibis) }\end{array}$ & 2 & 37.5 & 36.8 & - & 3.3 & 0.5 \\
\hline
\end{tabular}

References: 1. Grant. G. (pers. comm.). 2. Vleck et al. 1983. 3. Barrett 1980. 


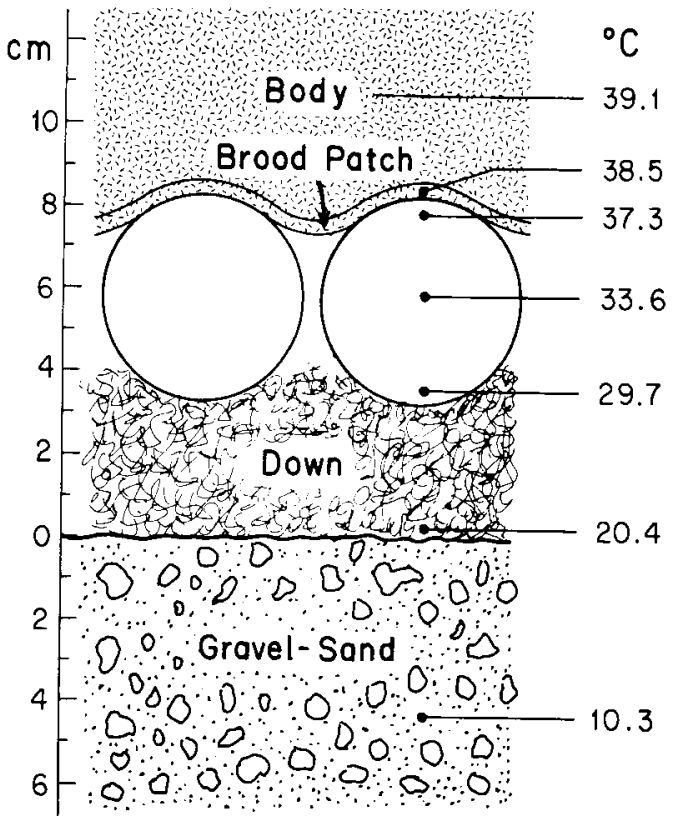

Fig. 4. Composite of various temperatures measured to show the heat gradients in the Eider's nest. A distance scale is on the left.

Nest air temperatures. - This is the temperature found between the eggs. These were measured continuously over a 5 -hour period in the nest of the Long-tailed Duck during the first week after clutch completion and varied between 33 and $34^{\circ} \mathrm{C}$. As pointed out by Drent $(1970,1975)$, nest air temperature of the Herring Gull increases gradually over the first ten days of incubation and during this time may actually exceed the central or air cell egg temperature. Measurements of nest air temperatures for other waterfowl have been reported for Anas acuta, $35.9^{\circ} \mathrm{C}$ (Irving \& Krog 1956), for Mergus serrator, $36.9^{\circ} \mathrm{C}$ (Barth 1949), and for the Domestic Goose, $33.4^{\circ} \mathrm{C}$ (Koch \& Steinke 1944). Lomholt (1976) measured the air temperature and relative humidity 'below the eggs' of Eiders and reported a value between 27 and $29^{\circ} \mathrm{C}$, which is close to our bottom values inside the egg, namely, $29.7^{\circ} \mathrm{C}$ (see Fig. 4 and Table 7). Nest air values for other non-passeriform birds have been reported by Drent (1975), and for 16 species these average $34.8^{\circ} \mathrm{C}$, S.D. 1.3 .

Overall temperature gradient. - In Fig. 4 we have combined our various temperature measurements for the nest and the egg of the Eider. The scale on the left indicates the spatial arrangement and on the right the continuous temperature gradient. These nests were located on a moraine close to the bay and the daily average air temperature varied between 3 and $4^{\circ} \mathrm{C}$. It is interesting to note that the temperature gradient of the egg, as previously noted, was approximately $1.5^{\circ} \mathrm{C} / \mathrm{cm}$, while the gradient across the $3.8 \mathrm{~cm}$ of down as well as across $4 \mathrm{~cm}$ of soil was similar, namely, ca. $2.4^{\circ} \mathrm{C} / \mathrm{cm}$.

When these temperatures are compared with those of other waterfowl nesting in more temperate climates there are no essential differences, thus confirming the observations of Irving \& Krog (1956) that the arctic environment does not compromise normal egg and nest temperatures in these species. As far as our egg temperatures are concerned, it is important to bear in mind that these represent the situation during the early stages of incubation. As the chorioallantoic circulation becomes established, it will have a great effect on redistributing the heat more evenly throughout the egg, thus diminishing the large gradients seen in Fig. 4. The chorioallantois begins to make contact with the inner shell membrane about day 6 in the chicken and finally envelops the whole shell by day 12 , that is, after only $60 \%$ of the incubation period has been completed. It is at that time that the rapid growth of the embryo begins to contribute to the heat balance of the egg. It is therefore not until the last quarter of the incubation that one would expect to see temperature gradients within the egg reach their minimal values. As we shall see, these are important considerations for predicting the mean temperatures of the egg, since they determine the water vapor pressure head responsible for the incubation water loss.

\section{Nest humidity}

The rate of water loss from the egg is equal to the product of the shell conductance and the water vapor pressure difference between the egg and that of the nest air. The vapor pressure of the nest air is therefore an important factor in the regulation of water loss. Since arctic climates have a very low absolute humidity or vapor pressure, it was of particular interest to see how nest humidity in the Spitsbergen area compared with that of nests in more humid and temperate climates.In Table 8 we have compared our average values with those obtained in the nests of other waterfowl nesting in temperate regions. 
Table 8. Absolute nest humidities (torr) in nests of waterfowl measured with egg hygrometers. The values reported for Lomholt (1976) and Koch \& Steinke (1944) were calculated from their measurements of relative humidity and temperature of nest air.

\begin{tabular}{|c|c|c|c|}
\hline & $\begin{array}{l}\text { Nest humidity } \\
\text { (torr) }\end{array}$ & No. obs. & Reference \\
\hline Eider & 19.2 & 2 & - \\
\hline (Somateria mollissima) & 21.0 & - & Lomholt (1976) \\
\hline $\begin{array}{l}\text { Barnacle Goose } \\
\text { (Branta leucopsis) }\end{array}$ & 17.3 & 6 & - \\
\hline $\begin{array}{l}\text { Long-tailed Duck } \\
\text { (Clangula hyemalis) }\end{array}$ & 14.9 & 2 & - \\
\hline $\begin{array}{l}\text { Domestic Goose } \\
\text { (Anser sp.) }\end{array}$ & 14.0 & - & Koch \& Steinke (1944) \\
\hline $\begin{array}{l}\text { Snow Goose } \\
\text { (Anser caerulescens) }\end{array}$ & 24.2 & 7 & Rahn et al. (1977) \\
\hline $\begin{array}{l}\text { Greylag Goose } \\
\text { (Anser anser) }\end{array}$ & 22.3 & 5 & Rahn et al. (1977) \\
\hline $\begin{array}{l}\text { Egyptian Goose } \\
\text { (Alopochen aegyptiacus) }\end{array}$ & 19.2 & 3 & Rahn et al. (1977) \\
\hline $\begin{array}{l}\text { Mallard Duck } \\
\text { (Anas platyrhynchos) }\end{array}$ & 17.4 & 3 & Rahn et al. (1977) \\
\hline
\end{tabular}

There appears to be no essential difference and this suggests that these arctic nests are so well insulated against the dissipation of water vapor through the nesting material and the protecting feathers that values characteristic of temperate climates are maintained.

\section{Egg water loss during incubation}

Although the rate of water loss is now known for more than 80 species (Ar \& Rahn 1980). it includes only one species of waterfowl, namely, the Eider. Hagelund \& Norderhaug (1975) studied the weight loss of Eiders in Spitsbergen over a period of 20 days. In seven broods (33 eggs), the average weight loss was $625 \mathrm{mg} \mathrm{day}^{-1}$. Extrapolated over their reported incubation period of 24.3 days this represents $14.5 \%$ of their initial egg mass of $104.5 \mathrm{~g}$. Belopolski (1961) reported the weight loss of eleven Eider eggs in the Barents Sea area with an initial mass of $102 \mathrm{~g}$. Over a 25-day incubation period these lost $16.6 \mathrm{~g}$, an average daily weight loss of $660 \mathrm{mg}$ day $^{-1}$. These values may be compared with our value of $590 \mathrm{mg} \mathrm{day}^{-1}$ over a four-day period (Table 4). Assuming this to represent the average value over a 25-day period of incubation, their total loss would be $14.8 \mathrm{~g}$, or $14.3 \%$ of their initial mass of $103 \mathrm{~g}$, very close to the average value reported for birds in general (Ar \& Rahn 1980). The Barnacle Goose eggs over a 19-day interval lost on the average $572 \mathrm{mg} \mathrm{day}^{-1}$. Multiplying this value by 24.5 days of incubation (Johnsgard 1978) predicts a total weight loss of $14 \mathrm{~g}$, or $13 \%$ of their initial mass of $109 \mathrm{~g}$.

\section{Relation between egg woter loss, egg temperature} and nest humidity

To ensure a given incubation water loss of the egg, the shell conductance must be exposed to a finite nest temperature and humidity. During development, the oxidation of solids and the formation of metabolic water will each contribute to an appreciable increase in the relative water content of the eggs unless it is removed by diffusion through the pores. Knowing the metabolic rate throughout incubation, one can calculate that to achieve a relative water content at the end of incubation equal to that of the fresh egg, about $15 \%$ of the initial egg mass must be lost as water. Recent measurements of the relative water content of precocial eggs have shown that indeed this value is the same $(72 \%)$ for hatchlings and the fresh egg in spite of a water loss equal to about $15 \%$ of the initial egg mass. On the basis of these observations Ar \& Rahn (1980) have proposed that a particular incubation water loss is mandatory for optimal hatching success.

We may now consider the nest conditions prerequisite for incubating eggs losing the proper amount of water. The rate of egg water loss is a physical phenomenon dependent on the escape of water vapor by diffusion across the pores of 
the shell. It can be described as follows (Rahn et al. 1976):

$$
\dot{\mathrm{M}}_{\mathrm{H}_{2} \mathrm{O}}=\mathrm{G}_{\mathrm{egg}}\left(\mathrm{P}_{\mathrm{A}}-\mathrm{P}_{\mathrm{N}}\right)_{\mathrm{H}_{2} \mathrm{O}}
$$

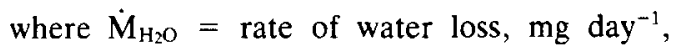
$\mathrm{G}_{\mathrm{egg}}=$ water vapor conductance of the shell, $\mathrm{mg}$ day ${ }^{-1}$ torr $^{-1}, \mathrm{P}_{\mathrm{A}}=$ water vapor pressure in the egg, torr, and $P_{N}=$ water vapor pressure in the nest air surrounding the egg, torr. Substituting into equation (1) the values for the Eider, where $\mathrm{M}_{\mathrm{H}_{2} \mathrm{O}}=590 \mathrm{mg}$ day $^{-1}$ (Table 4) and $\mathrm{G}_{\mathrm{egg}}=$ $21.6 \mathrm{mg} \mathrm{day}^{-1}$ torr $^{-1}$ (Table 6), one obtains the water vapor pressure difference $\left(P_{A}-P_{N}\right)$ which must have existed between the egg and nest air and is equal to 27.3 torr. Since we also know the vapor pressure of the Eider nest, $P_{N}=19.2$ torr (Table 3) we can add these two values $(19.2+27.3)$ to obtain the water vapor pressure of 46.5 torr that must have existed in the egg, $\mathrm{P}_{\mathrm{A}}$. The water vapor pressure in the air spaces of the membranes beneath the shell is essentially saturated, and thus one obtains from this value the average temperature of the egg, which according to the vapor pressure-temperature tables is $36.8^{\circ} \mathrm{C}$. Similar calculations for the eggs of the Barnacle Goose predict a temperature of $35.2^{\circ} \mathrm{C}$. Both of these values are similar to the central or

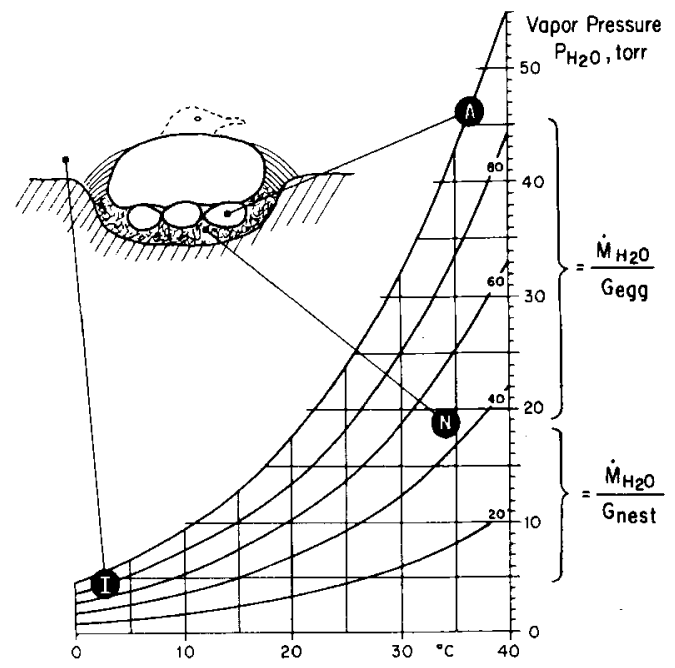

Fig. 5. Simultaneous values of temperature and absolute humidity values found in the egg of the incubating Eider, A, the nest air, $\mathrm{N}$, and the ambient environment, $\mathrm{I}$. Curve on the left is saturation water vapor pressure at various temperatures equivalent to $100 \%$ relative humidity. Curves to the right are isopleths for relative humidity values of $80,60,40$, and $20 \%$. (For discussion see text.) air cell temperature of other waterfowl eggs discussed above as well as the average egg temperature value for non-passeriform eggs in general, namely, $35.8^{\circ} \mathrm{C}$ (Drent 1975 ).

In Fig. 5 are shown the water vapor temperature coordinates where the left hand curve represents saturation water vapor pressure $(=$ dew point or $100 \%$ relative humidity). The other curves represent isopleths for relative humidity of $80,60,40$, and $20 \%$. Point $A$ represents the air space benetah the shell which is saturated at 46.5 torr at $36.8^{\circ} \mathrm{C}$. Point $\mathrm{N}$ represents the vapor pressure of the nest $=19.2$ torr. This point was arbitrarily placed at a temperature of $34^{\circ} \mathrm{C}$, an average value for nest air temperature (Drent 1975). However, this point can be moved to the right or the left along the 19.2 vapor pressure sopleth when better values for nest air temperature are eventually obtained. The exact location is of importance only if one wants to obtain a more reliable value for calculating the relative nest humidity. At present, this is shown at ca. $50 \%$.

For our purposes, the important difference is the vapor pressure difference between the egg and the nest $\left(\mathrm{P}_{\mathrm{A}}-\mathrm{P}_{\mathrm{N}}\right)$, where $\mathrm{P}_{\mathrm{A}}$ is determined by the egg temperature and $P_{N}$ by the nest construction, feather cover, and brooding behavior of the parent. For a given value of $\left(P_{A}-P_{N}\right)$, the rate of water loss depends on the magnitude of the shell conductance, $\mathrm{G}_{\mathrm{egg}}$. By rearranging equation (1), $\left(\mathrm{P}_{\mathrm{A}}-\mathrm{P}_{\mathrm{N}}\right)=\dot{\mathrm{M}}_{\mathrm{H}_{2} \mathrm{O}} / \mathrm{G}_{\mathrm{egg}}$ as shown on the right ordinate of Fig. 5. In the case of the Eider, the required conductance is established in utero long before incubation begins by the formation of 14,000 pores which have an average length of $370 \mu \mathrm{m}$ and an effective radius of $9 \mu \mathrm{m}$ (Table 6).

\section{Nest conductance}

Water vapor released from the egg cannot accumulate in the nest without raising its vapor pressure. It must therefore escape by diffusion and/ or convection across the nest and feather barrier. In the steady state the rate of water vapor escape from the nest must equal the escape rate from the egg, assuming that additional release of water vapor from the brood patch is negligible. Thus one can write an equation for water loss from the nest, where

$$
\mathrm{M}_{\mathrm{H}_{2} \mathrm{O}}=\mathrm{G}_{\text {nest }}\left(\mathrm{P}_{\mathrm{N}}-\mathrm{P}_{\mathrm{I}}\right)
$$


where $\mathrm{M}_{\mathrm{H}_{2} \mathrm{O}}=$ rate of water loss for each egg from the nest and is assumed to be equal to the rate of water loss from the egg, $\mathrm{mg} \mathrm{day}^{-1}, \mathrm{G}_{\text {nest }}=$ the water vapor conductance of the nest, assumed to be by diffusion only, $\mathrm{mg}$ day $\mathrm{y}^{-1}$ torr $^{-1}, \mathrm{P}_{\mathrm{N}}=$ water vapor pressure of the nest, torr, and $P_{I}=$ water vapor pressure of the ambient environment, torr.

The mean ambient vapor pressure. $P_{I}$, was equal to 4.0 torr. Substituting this value in equation (2) allows one to obtain the water vapor conductance of the nest per egg, $\mathrm{G}_{\text {nest }}=590 /$ $(19.2-4.0)=39 \mathrm{mg} \mathrm{day}^{-1}$ torr $^{-1}$. nearly twice the value of the egg conductance. On the right ordinate of Fig. 5 the bracket indicates the $\left(P_{N}-P_{1}\right)$ difference which is determined by the ratio of $M_{\mathrm{H}: \mathrm{O}} / \mathrm{G}_{\text {nes! }}$.

\section{Comparison of dry and moist climates}

In view of a prescribed incubation water loss it is of interest to compare the effects of a dry climate such as Spitsbergen's with a moist climate of the tropics on the development of nest and eggshell conductance. Point $I$ in Fig. 6 described the ambient atmosphere, $P_{I}$, at Spitsbergen at $3^{\circ} \mathrm{C}$, relative humidity $70 \%$, and an absolute

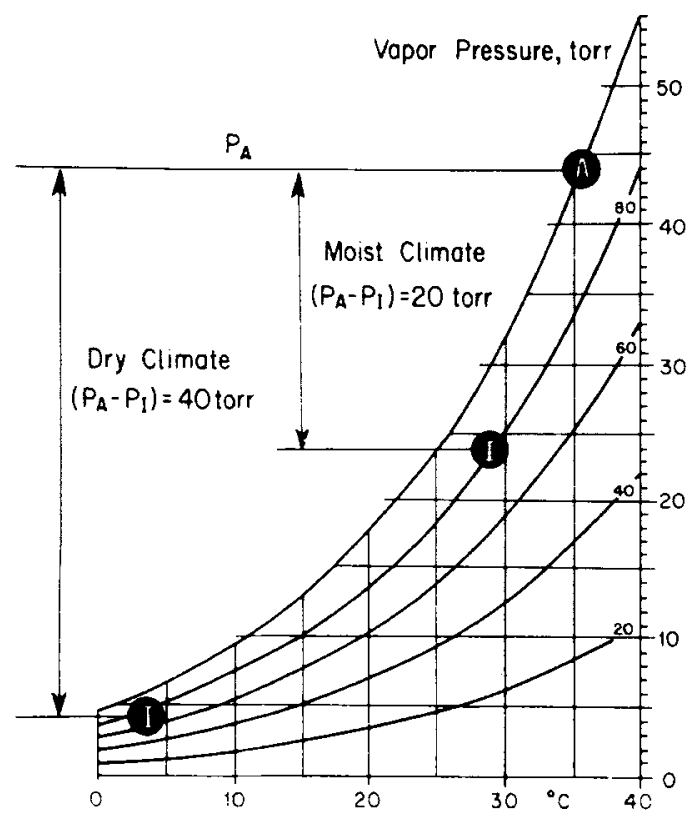

Fig. 6. Comparison of the total water vapor pressure difference $\left(P_{A}-P_{I}\right)$ in dry-cold and in moist-warm climates. (For discussion see text.) humidity of 4 torr. During the nesting season the ambient atmosphere of Enewetak Island in the Pacific has a mean temperature of $28^{\circ} \mathrm{C}$, relative humidity $80 \%$, and an absolute humidity of 24 torr (Fig. 6) (Rahn et al. 1976). Each value, 4 and 24 torr, represents the final sink for water vapor diffusion. Assuming in each region an egg temperature of $36^{\circ} \mathrm{C}$ equivalent to an egg vapor pressure of 44 torr, then the total pressure difference $\left(P_{A}-P_{I}\right)$ available for the dissipation of water vapor is $(44-4)$ or 40 torr in the dry climate of Spitsbergen and $(44-24)$ or 20 torr in the moist climate of Enewetak as illustrated in Fig. 6. In each case this pressure difference must be divided between that acting across the eggshell and that acting across the nest-feather barrier, since $P_{A}-P_{I}=\left(P_{A}-P_{N}\right)+\left(P_{N}+P_{I}\right)$. Since the flux rate of water vapor is assumed to be the same for the egg and the nest, equations (1) and (2) can be substituted and rearranged to yield

$$
\frac{P_{A}-P_{I}}{\dot{M}_{H_{2} \mathrm{O}}}=\frac{1}{G_{\text {egg }}}+\frac{1}{G_{\text {nest }}}
$$

and since $1 / G=$ the resistance, $R$

$$
\frac{P_{A}-P_{I}}{\dot{M}_{\mathrm{H}_{2} \mathrm{O}}}=R_{\text {egg }}+R_{\text {nest }}
$$

Thus for a given water loss rate in both climates, $\left(R_{\text {egg }}+R_{\text {nest }}\right)$ is half as large (and $G$ twice as large) in the moist climate as in the dry.

This does not mean that the eggshell resistance in the dry climate is necessarily half as large (or $\mathrm{G}_{\text {egg }}$ twice as large), since the particular value of the $R_{\text {egg }}$ will also depend on the changes in $R_{\text {nest }}$ (equation (3)), and the ratio of $R_{\text {egg }}$ to $R_{\text {nest }}$ will vary with each species. However, it emphasizes that each climate imposes a finite total water vapor pressure difference, $P_{A}-P_{I}\left(P_{A}\right.$ determined by the egg temperature and $P_{I}$ by the climate), and that the adaptive shell resistance depends upon the nest resistance, as their sums must equal $\left(\mathrm{P}_{\mathrm{A}}-\mathrm{P}_{1}\right) / \mathrm{M}_{\mathrm{H}_{2} \mathrm{O}}$ according to equation (3). Egg resistance in each species is determined by the number of pores, their length and crosssectional area, while a given nest resistance is achieved by the nest construction and the brooding behavior and attentiveness of the parent.

Acknowledgements. - These studies were carried out in June and July 1982 at the Norwegian Polar Research Institute at $\mathrm{Ny}$-Ålesund. Svalbard. and were supported in part by the Bell 
Fund and the Distinguished Professor Fund of the State University of New York at Buffalo to Hermann Rahn. The authors take pleasure in acknowledging the help of many others who assisted in these studies, particularly Øivind Tøien.

\section{References}

Ar, A., Paganelli, C. V., Reeves, R. B., Greene, D. G. \& Rahn, H. 1974: The avian egg: water vapor conductance, shell thickness and functional pore area. Condor 76, 153158.

Ar, A. \& Rahn, H. 1978: Interdependence of gas conductance, incubation, length, and weight of the avian egg. Pp. 227-236 in J. Piiper (ed.) Respiratory Function in Birds, Adult and Embryonic. Springer Verlag.

Ar, A. \& Rahn, H. 1980: Water in the avian egg: Overall budget of incubation. Am. Zool. 20, 373-384.

Barrett. R. T. 1980: Temperature of Kittiwake Rissa tridactyla eggs and nest during incubation. Ornis scandinavica 11 , $50-59$.

Barth, E. K. 1949: Redetemperaturer og rugevaner. Naturen (Bergen) 73, 81-95.

Belopolski, L. O. 1961: Ecology of sea colony birds of the Barents Sea (Transl. from Russian edition, 1957). Israel Prog. Sci. Transl., Jerusalem.

Board, R. G. 1982: Properties of avian egg shells and their adaptive value. Biol. Rev. 57, 1-28.

Board, R. G., Tullett, S. G. \& Perrott, H. R. 1977: An arbitrary classification of the pore systems in avian egg shells. J. Zool. Lond. 182, 251-265.

Burke, E. 1925: A study of incubation. Mont. Agric. Exp. Sta. Bull. 178, 1-44.

Caldwell, P. J. \& Cornwell, G. W. 1975: Incubation behavior and temperatures of the Mallard Duck. $A u k$ 92, 706-731.

Carey, C. 1979: Increase in conductance to water vapor during incubation in eggs of two avian species. J. Exp. Zool. 209, 181-186.

Cooper, J. A. 1978: The history and breeding biology of the Canada Geese of Marshy Point, Manitoba. Wildlife Monographs No. 61, 1-87.

Drent, R. H. 1970: Functional aspects of incubation in the Herring Gull. Behaviour, Suppl. 17, 1-132.

Drent, R. H. 1975: Incubation. pp. 334-420 in Farner, D. S. \& King, J. R. (eds.): Avian Biology Vol. 5. Academic Press, N.Y.

Grant, G. S., Paganelli, C. V., Pettit, T. N. \& Whittow, G.
C. 1982: Determination of fresh egg mass during natural incubation. Condor 84, 121-122.

Hagelund, K. \& Norderhaug, M. 1975: Studies of population changes and breeding processes in a colony of Eiders (Somateria mollissima (L)) in Svalbard. Norsk Polarinstitutt Årbok 1973, 141-162.

Hanka, L. R., Packard, G. C., Sotherland, P. R., Taigen, T. L., Boardman, T. J. \& Packard, M. J. 1979: Ontogenetic changes in water-vapor conductances of eggs of yellowheaded blackbirds (Xanthocephalus xanthocephalus). J. Exp. Zool. 210, 183-188.

Huggins, R. A. 1941: Egg temperatures of wild birds under natural conditions. Ecology 22, 148-157.

Irving, L. \& Krog, J. 1956: Temperature during development of birds in arctic nests. Physiol. Zool. 29, 195-205.

Johnsgard, P. A. 1978: Ducks, Geese, and Swans of the World. Univ. Nebraska Press, Lincoln, Nebraska. 404 pp.

Koch, A. \& Steinke, L. 1944: Über Temperatur and Feuchtigkeit bei Natur und Kunstbrut. Arch. Kleintierzucht 3, 153203.

Kossack, C. W. 1947: Incubation temperatures of Canada Geese. J. Wildlife Manage. 11, 119-126.

Lomholt, J. P. 1976: Relationship of weight loss to ambient humidity of bird eggs during incubation. J. Comp. Physiol. 105, 189-196.

Paganelli, C. V. 1980: The physics of gas exchange across the avian eggshell. Am. Zool. 20, 329-338.

Paganelli, C. V., Olszowka, A. \& Ar, A. 1974: The avian egg: surface area, volume and density. Condor 76, 319-325.

Rahn, H., Paganelli, C. V., Nisbet, I. C. T. \& Whittow, G. C. 1976: Regulation of incubation water loss in eggs of seven species of Terns. Physiol. Zool. 49, 245-259.

Rahn, H., Ackerman, R. A. \& Paganelli, C. V. 1977: Humidity in the avian nest and egg water loss during incubation. Physiol. Zool. 50, 269-283.

Rahn, H., Parisi, P. \& Paganelli, C. V. 1982: Estimating the initial density of birds' eggs. Condor 84, 339-341.

Rol'nik, V. V. 1970: Bird embryology (Transl. from the Russian edition, 1968). Israel Prog. Sci. Transl., Jerusalem.

Schönwetter, M. 1960; Handbuch der Oologie. Meise, W. (ed.). Akademie Verlag. Berlin.

Sotherland, P. R., Packard, G. C. \& Taigen, T. L. 1980: An altitudinal cline in conductance of Cliff Swallow eggs to water vapor. Auk 97, 177-185.

Tyler, C. 1964: A study of the egg shells of the Anatidae. Proc. Zool. Soc. Lond. 142, 547-583.

Vleck, C. M., Vleck, D., Rahn, H. \& Paganelli, C. V. 1983: Nest microclimate, water vapor conductance and water loss in heron and tern eggs. Auk 100, 76-83. 
